\section{Social inequalities and the rise in violent deaths in Salvador, Bahia State, Brazil: 2000-2006}

\author{
Desigualdades sociais e crescimento das mortes \\ violentas em Salvador, Bahia, Brasil: 2000-2006
}

Luiz Antonio Chaves Viana 1

Maria da Conceição Nascimento Costa 1

Jairnilson Silva Paim 1

Ligia Maria Vieira-da-Silva 1

\footnotetext{
1 Instituto de Saúde Coletiva,Universidade Federal da Bahia, Salvador, Brasil.

Correspondence M. C. N. Costa Instituto de Saúde Coletiva, Universidade Federal da Bahia.

Rua Basílio da Gama s/n, Salvador, $B A$ 40110-040, Brasil. mcncosta@ufba.br
}

\begin{abstract}
An ecological study was carried out using information zones as units of analysis in order to assess the evolution of socio-spatial inequalities in mortality due to external causes and homicides in Salvador, Bahia State, Brazil, in 2000 and 2006. The Brazilian Institute of Geography and Statistics (Instituto Brasileiro de Geografia e Estatística - IBGE) and the City Health Department (Secretaria Municipal de Saúde) provided the data sources, and causes of death were reviewed and reclassified based on reports from the Institute of Legal Medicine (Instituto Médico Legal). The information zones were classified into four social strata according to income and schooling. The ratio between mortality rates (inequality ratio) was calculated and confirmed a rise of $98.5 \%$ in the homicide rate. In 2000, the risk of death due to external causes and murders in the stratum with the worst living conditions was respectively 1.40 and 1.94 times greater than in the reference stratum. In 2006 these figures were 2.02 and 2.24. The authors discuss the implications for intersectoral public policies, based on evidence from the study's findings.
\end{abstract}

Social Inequity; Violence; Homicide

\section{Introduction}

Over the last three decades, there has been a reemergence of interest in social inequality within several scientific disciplines and among governmental institutions worldwide, particularly in view of its relationship with health-disease processes, making it a universal and persistent phenomenon 1,2 . Several studies have demonstrated that in those countries with higher relative inequalities in living conditions and income distribution there is a marked disparity in health indicators between social classes. One of the explanations for this fact is that these societies generally tend to be less cohesive, with negative effects on health conditions of disadvantaged populations $3,4,5,6,7$. Indeed, in recent years, social inequalities in health between countries and internally within each country have increased 8 .

A range of authors, who have dealt with this theme from different theoretical perspectives and in empirical research ${ }^{9}$, have noted the relevance of analyzing this factor in studies regarding the incidence of illnesses within populations. Such inequalities are important factors in establishing the profile of morbidity and mortality indicators from external causes, including homicides 10,11,12,13. The World Health Organization (WHO) estimated the homicide rate of 155/100,000 for the Americas, in 2004, with a large differential between those with a high income $(18 / 100,000)$ and those with a low income $(137 / 100,000) 14,15$. 
In Brazil, mortality due to external causes had risen from fourth place at the beginning of the 1980 s to second place by 1989 . In 2002, the risk of death from these causes was 71.6/100,000 inhabitants, which constituted $12.6 \%$ of all causes of death 16. It is also worth noting that homicide is the principal cause of premature death, and has the greatest impact on young males 17. A linear increase can be seen in homicides between 1979 and 2001 with an increase in the involvement of firearms from $43 \%$ to $69 \% 18$.

Urban violence is most apparent in the capital cities and metropolitan regions, affecting the population with the worst living conditions. In 2003, the risk of violent death increased to 28.9/100,000 with a significant discrepancy between capital cities, the lowest being Natal $(18.5 / 100,000)$ and the highest Recife $(66.4 / 100,000) 16$. Investigations carried out in Brazil point to social inequality as one of the main factors responsible for the growth in urban violence, and also demonstrate differentials in mortality due to violence in terms of gender, race, age group, social class and place of residence 12,19,20,21.

The monitoring of the intra-urban differentials of violent deaths identified zones in Salvador, Bahia, with much higher mortality rates due to external causes as compared to other localities in Brazil 22. Studies carried out in this municipality revealed an unequal socio-spatial distribution, with the highest rates occurring in populations with the worst living conditions. Homicides remained stable from the 1990s to 2000 reaching a rate of $33 / 100,000$ in 2001 . However, these rates increase when sex, age group and socio-spatial distribution are taken into account $23,24,25,26$. In 2000, the total rate for homicides in some poor neighborhoods in the city was in excess of 100/100,000 22. Moreover, between 1998 and 2003, mortality due to external causes was of 14,507 potential years of life lost/100,000 inhabitants, of which $62 \%$ were due to homicides 27 .

The magnitude and relevance of the problem of violent deaths in Salvador reveal the importance of maintaining up-to-date information about social inequalities as they occur, especially given the fact that since the second half of the 20th century, the city has undergone transformations in its urban space and became a complex conurbation, fraught with problems, including urban violence 28 . On the other hand, certain reductions in homicide rates have been observed across Brazil and in some capital cities, as well as a certain "ruralization" of violence, which affects small and medium sized towns and cities. On this basis, this study sought to investigate the recent situation in Salvador in order to verify whether the observed inflection in national averages is also taking place in this capital. The objective of this study was, therefore, to examine the evolution of socio-spatial inequalities in mortality from external causes (in total and by homicide) within Salvador, in the years 2000 and 2006.

\section{Methods}

An ecological study of mortality due to external causes (International Classification of Diseases - ICD-10, chapter XX, codes V01-Y98), particularly homicides, was carried out, in 2000 and 2006, among residents from Salvador, with zones of information and social strata as the units of analysis. The information zones correspond to the subdivision of the municipal territory in areas defined by the Company for the Development of the Metropolitan Region of Salvador (Companhia de Desenvolvimento da Região Metropolitana de Salvador - CONDER), according to physical-urban, administrative and planning criteria. These areas are compatible with the census sectors of the Brazilian Institute of Geography and Statistics (Instituto Brasileiro de Geografia e Estatística - IBGE).

The City Health Department (Secretaria Municipal de Saúde - CHD) supplied the data on deaths in digital format, whilst information about socio-economic variables (head of household's income and schooling) were distributed by census sectors and came from the 2000 Demographic Census (IBGE. http://www.ibge.gov.br). The residential addresses of the deceased were geo-referenced by information zone, through the use of the LOCALIZA software (Instituto de Saúde Coletiva, Universidade Federal da Bahia, Salvador, Brazil). Maps and Google Earth (http:// www.google.com.br/intl/pt-BR/earth/index. html) were also used when address records were incomplete.

To improve the quality of information concerning the nature of death (when this was not clearly specified on the Death Certificate) a review was conducted for the years 2000 and 2006 through consultation with expert reports, police reports and other documents available at the Nina Rodrigues Institute of Legal Medicine (Instituto Médico Legal Nina Rodrigues - IMLNR). The data contained in the police forms and technical reports on each death were transferred to a database established for that purpose. From this information, the underlying causes of death were coded in an attempt to establish, in general, the circumstance of death, and the object that caused the injury and, whenever possible, the legal cause of death. If there were no details in the 
Technical Police Department (Departamento de Polícia Técnica - TPD) report and if the police forms mentioned two or more causes, the first option was considered. If there were discrepancies between the TPD reports and the police forms in relation to the type of violent death, it was classified as "injuries that are ignored if they were accidentally or intentionally inflicted". Other details are described elsewhere 21 .

The data collected in the special form, including the recoded underlying cause, were classified using Epi Info software (Centers for Disease Control and Prevention, Atlanta, USA) and formed a complementary database linked to the original by the recorded number of death certificates received from the CHD. Thus, for every death from external causes, it was possible to identify the code for the cause established by CHD and also the new code set from the access to IMLNR records.

The existence of social inequalities in the spatial distribution of mortality by external causes and by homicides was evaluated using the same methodology as in previous research 30 using two proxy variables for living conditions: economic capital and cultural capital. These constructs were developed by Bourdieu 31, according to whom, classes and sub-divisions of classes of individuals place themselves in defined positions within the social space, particularly through the quantity and composition of their economic and cultural capital. Those variables were used by Bourdieu 32 himself in his book where he analyzed the relations between lifestyle and social space. Although his concept of cultural capital is much more complex, he found that cultural capital was greater as school grades improved. Part of this cultural capital is obtained within the family, part taught in school and part not taught at school. He explained this phenomenon with what he called the "noblesse obligée" effect or the effect of school title. People search for knowledge and develop cultural tastes that school does not teach because the social position they attain through their title creates that obligation.

The following stratification was established for economic capital and cultural capital: low economic capital (proportion of heads of household with an income up to the value of two minimum wages), medium economic capital (proportion of heads of household with an income of between two and five minimum wages), high economic capital (proportion of heads of household with an income greater than the value of five minimum wages); low cultural capital (proportion of heads of household with either no schooling or up to 7 years of schooling), medium cultural capital (proportion of heads of household with
8-14 years of schooling) and high cultural capital (proportion of heads of household with 15 years of schooling or more). A second stratification was subsequently carried out according to the composition (greatest proportion in the zones of information) of economic capital and cultural capital: high social stratum (high cultural capital - HCC/high economic capital - HEC), intermediate social stratum (medium cultural capital MCC/high economic capital - HEC), low social stratum (medium cultural capital - MCC/low economic capital - LEC) and very low social stratum (low cultural capital - LCC/low economic capital - LEC), which will henceforth be called strata I, II, III and IV respectively. Taking zone of information 2 as an example of how this allocation was carried out, we see that it was composed of $12.8 \%$ of heads of household in LEC, $8.7 \%$ in MEC and $78.4 \%$ in HEC; $9.9 \%$ in LCC, $37.3 \%$ in MCC and $52.8 \%$ in HCC, and was thus classified as high social status (HCC/HEC), i.e. it was allocated to stratum I. Zones of information in which the difference between the proportion of heads of household for economic capital or for cultural capital was less than $10 \%$ were distributed systematically in order to ensure that half of the zones of information were allocated to each stratum. Zone of information 1, for example, had $41.9 \%$ of heads of household in the MCC stratum and $48.7 \%$ in the HCC and was randomly allocated to HCC.

We calculated crude and age-standardized mortality rates from external causes and homicides during the years of the study, and their respective percentage changes according to social strata. We used the population of Salvador in 2000 as standard. The age-standardized rates of each social stratum were represented on thematic maps using the ArcView 3.2 (Environmental Systems Research Institute Inc.; http://www. esri.com/software/arcview/) application. We estimated the inequality between the mortality of different social strata by calculating the ratio between the mortality rates (inequality ratio - IR) by external causes (total, homicides), allowing for a $95 \%$ confidence interval $(95 \% \mathrm{CI})$ and using the stratum of best socio-economic status as a reference. Epi Info 6.0 software was used for processing and data analysis.

This research proposal was submitted to and approved by the Ethics Research Committee at the Institute of Collective Health of the Bahia Federal University (Instituto de Saúde Coletiva, Universidade Federal da Bahia - ISC/UFBA) under registration no. 049/09. 


\section{Results}

In Salvador the mortality rate due to external causes per 100,000 inhabitants was 58.9 in 2000 and 65.1 in 2006, representing a rise of $10.5 \%$. In the same period this group of causes of death represented $10.9 \%$ and $12.9 \%$, respectively, of total deaths. For homicides, the rate was 20.0 per 100,000 in 2000 , rising to 39.7 per 100,000 in 2006 , an increase of $98.5 \%$. This cause, which in 2000 was responsible for $33.8 \%$ of the total deaths from deaths due to external causes, reached $60.9 \%$ in 2006. On the other hand, while violent deaths of indeterminate nature (ICD-10, chapter XX, codes Y10-Y34) contributed $16.3 \%$ of deaths by external causes in 2000 , this rate fell to $2.6 \%$ in 2006 . It was also observed that the proportion of deaths due to external causes for females was reduced from $17.7 \%$ in 2000 to $14.2 \%$ in 2006 , while the homicides increased from $8.3 \%$ to $14.5 \%$ in the same period.

In Table 1 we can see that, in the two years of the study, the mortality rates due to external causes were greater in the strata representing the worst living conditions, and that there was a percentage reduction in the two best social strata of $13.7 \%$ (stratum I) and $3.4 \%$ (stratum II) at the same time as a rise of $21.6 \%$ in stratum III and $13.4 \%$ in stratum IV. These differences are confirmed in the IR (Table 2), where we can see that the risk of death from external causes in stratum IV was 1.52 times higher compared to stratum I in 2000 and that this difference rose to 2.11 in 2006; these differences are statistically significant.

In respect of homicides (Table 3) we can see that, in 2000, strata I and IV presented, respectively, rates of 9.5 and 23.2 per 100,000 inhabitants. In 2006, the equivalent rates were 16.3 and 45.8 per 100,000 inhabitants. Between 2000 and 2006, social stratum I presented the lowest rise $(71.6 \%)$. The largest increases were in strata II (+102\%) and III (+ 121.7\%), while stratum IV, which represented the worst social conditions, showed a rise of $97.4 \%$. As regards the IR, there was a rise in stratum III from 1.94 (95\%CI: 1.103.43 ) to 2.24 (95\%CI: 1.52-3.29), whilst stratum IV showed a trend toward stability.

One can also see differences in the interurban distribution of deaths due to external causes and homicides, of which the highest rates per stratum were concentrated mainly around the suburban railway and the "core" of the city (known as the miolo), areas in this municipality that present a higher concentration of poverty (Figures 1 and 2).

\section{Discussion}

The increase in mortality due to external causes observed in Salvador in the period 2000-2006, especially in the sharp rise in homicides, for which the risk almost doubled over this short space of time, places this city amongst the most violent in the country and emphasizes the importance of this worsening problem both in terms of public health and public safety. In addition to the gradient presented, which shows an increase in the risk of death for this group of causes, moving across the population strata from the best to the worst living conditions, we should add the fact that while mortality rates due to external causes increased in the latter strata, the reverse was observed in the aggregates of better social indicators. Over the years studied, a worsening of inequalities in these causes of death can thus clearly be observed and is possibly related to social determinants. In turn, the increase of homicides among women has also been attributed to their greater involvement with illegal drug trafficking 33 .

The significant increase in the relative weight of homicide in the total number of deaths from external causes between 2000 and 2006 is striking when compared to previous years 21,24. However, the hypothesis that at least a certain amount of this increase is explained by the reduction of deaths from external causes of an "undetermined nature" is plausible, and it may be due to improved coding for cause of death.

Mortality due to homicides also followed a social gradient, since the increase in its occurrence also took place in inverse ratio to the population aggregates for living conditions. Notably, during the period of this study, although the risk of death from this cause increased across all social strata, the highest increases were registered in those with the worst living conditions. Thus, the inequality ratio remained unchanged in stratum IV (very poor living conditions) and increased in stratum III (poor living conditions). Although amounts were lower when compared to measurements obtained in a similar study 25 conducted in Salvador in 1991 and 1994, there was a trend toward intensification of the IR across the years of this study.

One can conclude from these findings that residential populations living in socially disadvantaged areas in Salvador have a higher risk of being victims of violent death, especially from homicide, which could indicate the existence of a homology between social space and the space of interaction and confrontation, expressed here in "forms of violent death".

The involvement of social inequalities in the incidence of deaths from external causes and 
Table 1

Crude and age-standardized rates of mortality due to external causes (per 100,000 inhabitants) and percentage variation ( $\Delta \%$ ) according to social strata. Salvador, Bahia State, Brazil, 2000 and 2006.

\begin{tabular}{|c|c|c|c|c|c|c|}
\hline \multirow[t]{2}{*}{ Social strata } & \multicolumn{2}{|c|}{2000} & \multicolumn{2}{|c|}{2006} & \multicolumn{2}{|c|}{$\Delta \%$ 2000-2006 } \\
\hline & Crude & Standardized & Crude & Standardized & Crude & Standardized \\
\hline 1 & 41.3 & 32.9 & 36.2 & 28.1 & -12.3 & -13.7 \\
\hline II & 48.3 & 41.4 & 47.7 & 40.0 & -1.2 & -3.4 \\
\hline III & 58.0 & 55.5 & 72.9 & 67.5 & +25.7 & +21.6 \\
\hline IV & 62.8 & 64.4 & 75.4 & 73.0 & +20.0 & +13.4 \\
\hline
\end{tabular}

I: HCC/HEC (high cultural capital/high economic capital); II: MCC/HEC (medium cultural capital/high economic capital); III: MCC/LEC (medium cultural capital/low economic capital); IV: LCC/LEC (low cultural capital/low economic capital).

Table 2

Inequality ratio * (IR) of death by external causes and homicides and $95 \%$ confidence intervals $(95 \% \mathrm{Cl})$ according to social strata. Salvador, Bahia State, Brazil, 2000 and 2006.

\begin{tabular}{|c|c|c|c|c|c|c|c|c|}
\hline \multirow[t]{3}{*}{ Social strata } & \multicolumn{4}{|c|}{2000} & \multicolumn{4}{|c|}{2006} \\
\hline & \multicolumn{2}{|c|}{ External causes } & \multicolumn{2}{|c|}{ Homicides } & \multicolumn{2}{|c|}{ External causes } & \multicolumn{2}{|c|}{ Homicides } \\
\hline & IR & $95 \% \mathrm{Cl}$ & IR & $95 \% \mathrm{Cl}$ & IR & $95 \% \mathrm{Cl}$ & IR & $95 \% \mathrm{Cl}$ \\
\hline I & 1.00 & - & 1.00 & - & 1.00 & - & 1.00 & - \\
\hline II & 1.10 & $0.81-1.49$ & 1.10 & $0.58-2.07$ & 1.31 & $0.96-1.79$ & 1.20 & $0.78-1.84$ \\
\hline III & 1.40 & $1.06-1.86$ & 1.94 & $1.10-3.43$ & 2.02 & $1.52-2.69$ & 2.24 & $1.52-3.29$ \\
\hline IV & 1.52 & $1.17-1.97$ & 2.44 & $1.43-4.17$ & 2.11 & $1.61-2.77$ & 2.43 & $1.68-3.49$ \\
\hline
\end{tabular}

I: HCC/HEC (high cultural capital/high economic capital) - reference; II: MCC/HEC (medium cultural capital/high economic capital); III: MCC/LEC (medium cultural capital/low economic capital); IV: LCC/LEC (low cultural capital/low economic capital).

* Rates were standardized by age.

Table 3

Crude and age-standardized rates of mortality due to homicides (per 100,000 inhabitants) and percentage variation ( $\Delta \%$ ) according to social strata. Salvador, Bahia State, Brazil, 2000 and 2006.

\begin{tabular}{|c|c|c|c|c|c|c|}
\hline \multirow[t]{2}{*}{ Social strata } & \multicolumn{2}{|c|}{2000} & \multicolumn{2}{|c|}{2006} & \multicolumn{2}{|c|}{$\Delta \%$ 2000-2006 } \\
\hline & Crude & Standardized & Crude & Standardized & Crude & Standardized \\
\hline I & 9.5 & 9.5 & 19.4 & 16.3 & +72.6 & +71.6 \\
\hline II & 10.4 & 10.1 & 24.2 & 20.4 & +132.7 & +102.0 \\
\hline III & 18.4 & 18.4 & 44.0 & 40.8 & +139.1 & +121.7 \\
\hline IV & 23.8 & 23.2 & 47.2 & 45.8 & +98.3 & +97.4 \\
\hline
\end{tabular}

I: HCC/HEC (high cultural capital/high economic capital); II: MCC/HEC (medium cultural capital/high economic capital); III: MCC/LEC (medium cultural capital/low economic capital); IV: LCC/LEC (low cultural capital/low economic capital).

homicides can also be observed in other cities in Brazil and also in other countries. Even with different methodologies, research conducted in cities in different regions of the country, such as Pernambuco, Rio de Janeiro, Sao Paulo, Paraná and Rio Grande do Sul consistently show that 

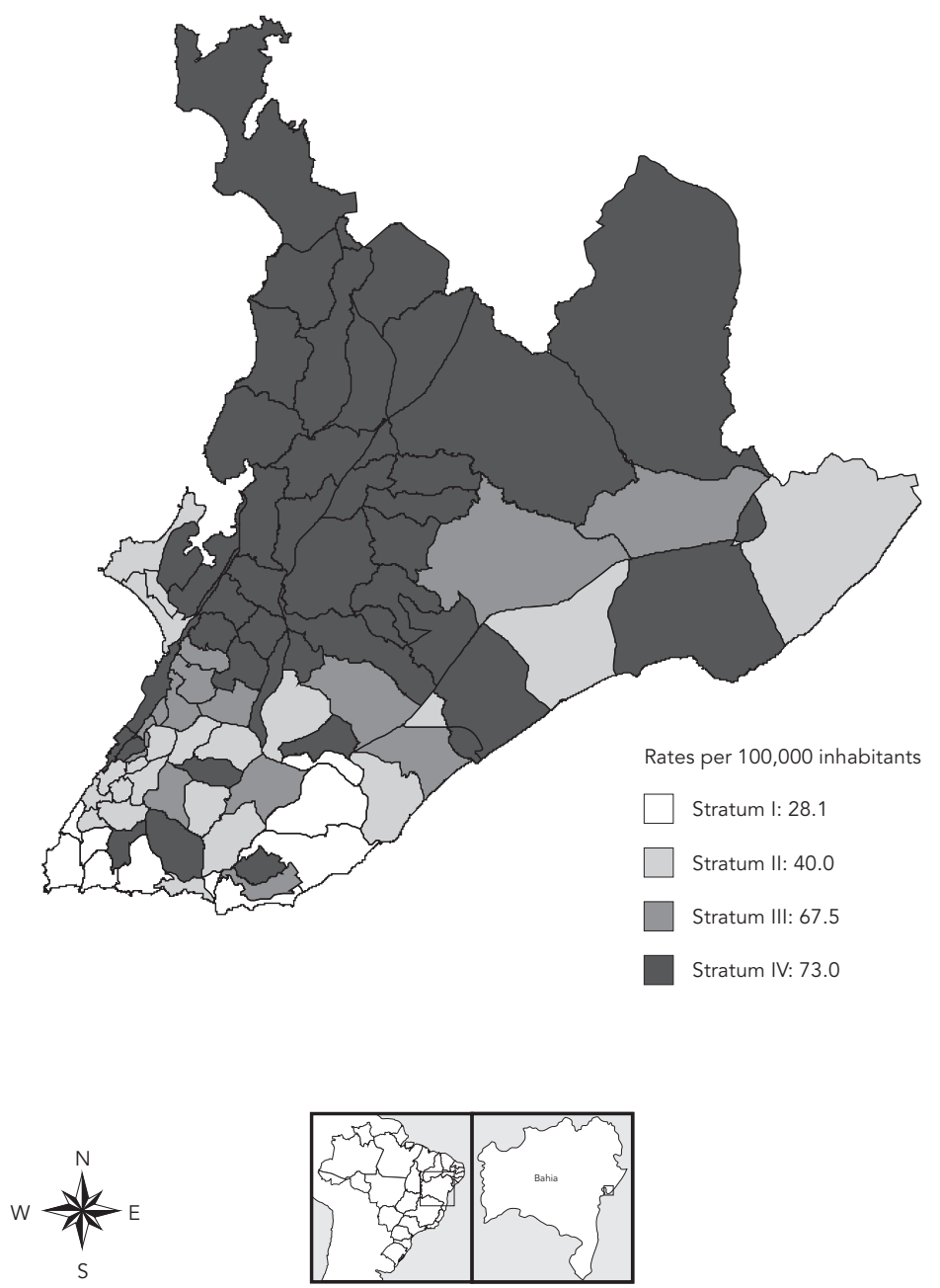

differences in living conditions represent a significant determinant in the socio-spatial distribution of violent deaths 13,14,20,34,35,36,37. Likewise, international investigations conducted in other socio-cultural contexts, even using different methodologies and theoretical approaches, indicate that local disadvantaged groups have a higher risk of violence, suggesting an association between inequality and homicide 38,39,40,41.
A transnational study also found that countries with high levels of inequality measured by the Gini index when controlling for other sociodemographic characteristics, displayed comparatively higher rates of homicide 42 . Also, a study comparing data from 33 countries showed a strong association between homicide rates and income inequality 43 . Other research, conducted in the USA from 1974 to 2000 , found that there 

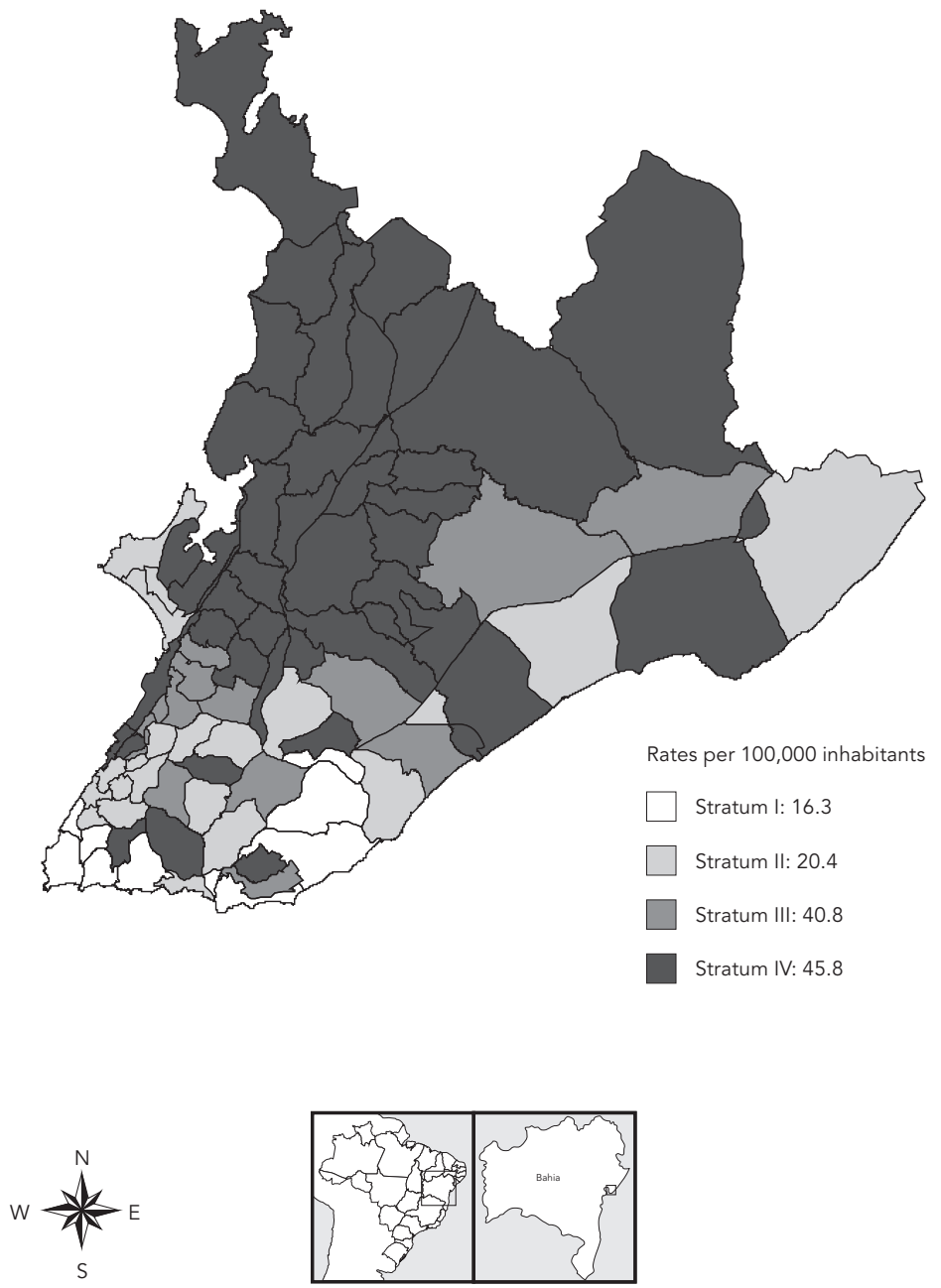

were greater reductions in crime rates among the rich compared to the poor, thus increasing disparity, and also demonstrated that the poor are victims of more severe crimes such as homicide 44 .

Despite an improvement in some social indicators in Salvador in the last two decades, such as the rise in the Human Development Index (HDI), increased per capita income, a reduction in the illiteracy rate and improved access to basic services and consumer goods, these advances do not, so far, seem to have had any positive impact on violence. A finding that is more consistent with the results of this study is that of worsening social inequality measured by an increase, albeit slight (0.65 in 1991 to 0.66 in 2000), in the Gini coefficient 45 .

Of particular note here is that the increase in violence, as seen in Salvador, in addition to social inequalities, possibly points to several determinants acting together, such as unemployment, 
organized crime, trafficking and drug abuse, a lack of confidence in the State's role as mediator in conflicts, devaluation and corruption of the justice system and the police force, the easy availability of firearms, and a lack of social support for disadvantaged populations, amongst other reasons highlighted in the literature 13,34,35,46. Thus, further studies are needed for a broadening of knowledge regarding the causes of this phenomenon in this city in order to improve the targeting of potential interventions.

While acknowledging the complexity of the relationships established between poverty, urban decay and violence 47 , studies have found a nonrandom spatial distribution, the result of a historical process of fragmentation and segregation, itself the result of changes in the urban fabric of Brazilian cities, including Salvador. Poverty, per $s e$, does not explain the high homicide rates; it can be explained by the set of social disadvantages to which the poor population is subjected 48 . Thus, although one can speak of a "geography of violence" 29 , we must remember that the relationship between violent deaths and areas with precarious living conditions involve multiple factors, that do not permit uncritical and linear linkages such as "violent places", poverty and violence or, much worse, poor people and violence. We can conclude that populations living in areas with the worst living conditions are the greatest victims of lethal violence.

Therefore, the relationship between inequalities in living conditions and homicide should not be treated as univocal, since other measures should also be considered, even though they may not always be quantifiable. The absolute (or relative absence of) state involvement in these territories, and the expansion of the business of drug trafficking, especially with the proliferation of crack, are variables that cannot be overlooked. This study and others that have been carried out do not demonstrate that poverty, in itself, generates violence, but the evidence indicates that social inequalities provide an explanatory matrix of the intra-urban differentials for homicide rates in the city.

Mutatis mutandis, one can also point out some similar elements in the analysis of violence in black American ghettos studied by Wacquant 48 and the outskirts of large Brazilian cities, including Salvador. According to this author, areas inhabited mainly by poor blacks in large cities of the USA suffered an uncivilizing process, ie a trend reversal of the historical transformations that occurred in the western world, which according to Elias 49 , resulted in a gradual pacification of society. The factors that may contribute to this transformation include the pacification of daily life, the erosion of public space, the absence of public services, unemployment and a growing informal economy.

Some issues should be considered in respect of this research, given that it is an ecological study aggregated by areas. Although ecological studies are regarded by some authors as appropriate and even necessary for the investigation of structural, contextual and macro-social factors in health 50 , they are subject to the effects of scale and aggregation of areas, as well as the definition of their borders, which means that the spatial definition of the area affects statistical results. As Schwartz 51 states, an aggregated variable can measure different constructs. Because of this, the unit of analysis should be the most homogeneous possible, in order to reflect the real situation of the subgroups it represents. To achieve this, the formation of small aggregates, that are as homogeneous as possible, is recommended 50,52. However, we should take into consideration the fact that reducing the units of analysis to very small groups raises the issue of obtaining random effects in the rates, or in other words, a loss of measurement stability 53 .

Therefore, as other authors have pointed out regarding this type of research, the results of this study should be interpreted with caution, given the limitations arising from the use of pre-defined geographical and administrative divisions as the unit of analysis, rather than areas that are more homogeneous in respect of socioeconomic conditions. The heterogeneity of the urban area of Salvador, where slums and middle and upper class neighborhoods co-exist, is a potential source of distortion in the classification utilized here 25,26,54.

As with any study developed from secondary data, this study is influenced by the quality of such data. To minimize this problem, with regard to the quality of diagnosis of type of death from external causes, the primary causes of death were reviewed and collated with information recorded at the ILMNR, as cited in the Methods section. Thus, we reiterate the need to review the autopsies and police reports from the ILMNR to determine the primary cause of death and reduce indices of violent deaths of an undetermined nature, thereby allowing the delineation of an epidemiological profile of mortality by external causes and homicides that is closer to reality. Thus, it is imperative to improve the generation of data (the full completion of the data registration instruments referred to above, including the Death Certificate) and a greater degree of consistency, integration and dissemination of the information systems related to morbidity-mortality by external causes and homicides. 
The current picture of violence in the country has prompted debates and plans involving various sectors of society 55,56,57, although it has not resulted in any effective and integrated longterm security policies. The reduction in levels of mortality due to external causes, particularly homicides, requires the integration of inter-sectoral planning involving health, justice, public safety, education, urban planning and the participation of social movements, interacting in synergy, prioritizing the relationship between social inequality, territory and violence in order to reduce the large numbers of preventable deaths and to advance the promotion of health and the reduction of iniquity, establishing ethical and political commitments to address a problem which has caused so much damage to society.

\section{Resumo}

Com o objetivo de analisar a evolução das desigualdades socioespaciais na mortalidade por causas externas e homicídios em Salvador, Bahia, Brasil, entre 2000-2006, foi realizado um estudo ecológico, tendo as zonas de informação e estratos sociais como unidades de análise. O Instituto Brasileiro de Geografia e Estatística (IBGE) e a Secretaria Municipal de Saúde foram fontes de dados. As causas básicas de óbito foram revisadas e reclassificadas com base em relatórios do IML. As zonas de informação foram classificadas em quatro estratos sociais a partir da renda e da escolaridade. Calculou-se a razão entre as taxas de mortalidade (razão de desigualdade). Verificou-se aumento de 98,5\% na taxa de homicídios no período. Em 2000, o risco de morte por causas externas e homicídios no estrato de piores condições de vida foi, respectivamente, 1,40 e 1,94 vezes maior que no estrato de referência. Em 2006, esses valores foram de 2,02 e 2,24. Os autores discutem as implicações para as políticas públicas intersetoriais evidenciadas pelos achados do presente estudo.

Iniquidades Social; Violência; Homicídio
In contrast to what was observed in Salvador between 1997 and 2000, which witnessed a decrease in homicides across all strata of living conditions and a persistence in the inequalities amongst risks for this cause of death 23 , this study shows a rise in violent deaths in this decade, contrary to both the national trend and that of certain other Brazilian capital cities. Hence the relevance of reflecting on this potential conclusion: "Good governments save lives and bad governments kill people. (...) All the actions and omissions of governments in relation to crime and violence must be understood as political choices (...) no matter the reasons - ignorance, doubts about effectiveness, fear of innovation or opposing interests (...). Inaction, in any form, including maintaining the status quo, is just as political as action, good or bad" $^{18}$ (p. 177).

\section{Contributors}

All the authors participated in the conception, design and execution of the project, as well as in the data analysis, in writing up the article, critical revision of intellectual content and approval of the final version.

\section{Acknowledgments}

The authors wish to acknowledge the financial support provided by CNPq. 


\section{References}

1. World Health Organization. Action on the social determinants on health: learning from previous experiences. Geneva: World Health Organization; 2005.

2. Buss PM, Pellegrini Filho A. A saúde e seus determinantes sociais. Physis (Rio J.) 2007; 17:77-93.

3. Castellanos PL. Epidemiologia, saúde pública, situação e condições de vida: considerações conceituais. In: Barata RB, editora. Condições de vida e situação de vida. Rio de Janeiro: ABRASCO; 1997. p. 3-75.

4. Subramanian SV, Belli P, Kawachi I. The macroeconomic determinants of health. Annu Rev Public Health 2002; 23:287-302.

5. Frohlich KL, Corin E, Potvin L. A theoretical proposal for the relationship between context and disease. Sociol Health Illn 2001; 23:776-97.

6. Kawachi I, Kennedy BP, Lochner P, Prothrow-Smith D. Social capital, income inequality and mortality. Am J Public Health 1997; 87:1491-8.

7. Kawashi I, Subramanian SV, Almeida-Filho N. A glossary for health inequalities. J Epidemiol Community Health 2002; 56:647-52.

8. Marmot M. Social determinants of health inequalities. Lancet 2005; 365:1099-104.

9. Almeida Filho N. Inequalities in health based on living conditions: analysis of scientific output in Latin American and the Caribean. Washington DC: Pan American Health Organization; 1999. (Research in Public Health. Technical Papers - ELAC Project, 19).

10. Szwarcwald CL, Bastos FI, Esteves MAP, Andrade CLT, Paez, MS, Medici EV, et al. Desigualdade de renda e situação de saúde o caso do Rio de Janeiro. Cad Saúde Pública 1999; 15:15-28.

11. Barata RB, Ribeiro MCS, Moraes JC. Desigualdades sociais e homicídios em adolescentes e adultos jovens na cidade de São Paulo em 1995. Rev Bras Epidemiol 2005; 2:50-9.

12. Gawryszewski VP, Costa LS. Homicídios e desigualdades sociais no Município de São Paulo. Rev Saúde Pública 2005; 39:191-7.

13. Reza A, Mercy JA, Krug E. Epidemiology of violent deaths in the world. Inj Prev 2001; 7:104-11.

14. World Health Organization. World report on violence and health. Geneva: World Health Organization; 2002.

15. World Health Organization. The global burden disease: 2004 update Geneva: World Health Organization; 2008.

16. Souza ER, Lima MLC. Panorama da violência urbana no Brasil e suas capitais. Ciênc Saúde Coletiva 2006; 11 Suppl:1211-22.

17. Reichenheim ME, Werneck GL. Anos potenciais de vida perdidos no Rio de Janeiro, 1990. As mortes violentas em questão. Cad Saúde Pública 1994; 10 Suppl 1:188-98.

18. Soares GAD. Não matarás: desenvolvimento, desigualdade e homicídios. Rio de Janeiro: Editora FGV; 2008.
19. Souza ER, Ximenes LF, Alves F, Magalhães C, Bilate D, Szuchmacher AM, et al. Avanços do conhecimento sobre causas externas no Brasil e no Mundo: enfoque quanti e qualitativo. In: Minayo MCS, Souza ER, organizadores. Violência sob o olhar da saúde: a infrapolítica da contemporaneidade brasileira. Rio de Janeiro: Editora Fiocruz; 2003. p. 131-62.

20. Costa IER, Ludermir AB, Silva IA. Diferenciais da mortalidade por violência contra adolescentes segundo estrato de condições de vida e raça/cor na cidade do Recife. Ciênc Sáude Coletiva 2009; 14:1781-8.

21. Paim JS, Costa MCN, Mascarenhas JCS, Silva LMV. Distribuição espacial da violência: mortalidade por causas externas em Salvador (Bahia), Brasil. Rev Panam Salud Pública 1999; 6:321-32.

22. Nunes M, Paim JS. Um estudo etno-epidemiológico da violência urbana na cidade de Salvador, Bahia, Brasil: os atos de extermínio como objeto de análise. Cad Saúde Pública 2005; 21:459-68.

23. Paim JS. Condições de vida, violências e extermínio. In: Carvalho I, Pereira GC, organizadores. Como anda Salvador e sua Região Metropolitana. Salvador: EdUFBA; 2008. p. 157-69.

24. Freitas ED, Paim JS, Silva LMV, Costa MCN. Evolução e distribuição espacial da mortalidade por causas externas em Salvador, Bahia, Brasil. Cad Saúde Pública 2000; 16:1059-70.

25. Macedo AC, Paim JS, Silva LMV, Costa MCN. Violência e desigualdade social: mortalidade por homicídios e condições de vida em Salvador, Brasil. Rev Saúde Pública 2001; 35:515-22.

26. Santana FS. Homicídios em Salvador 1998-2001: efeitos das desigualdades socioeconômicas na mortalidade por violência [Dissertação de Mestrado]. Rio de Janeiro: Escola Nacional de Saúde Pública, Fundação Osvaldo Cruz; 2004.

27. Araújo EM, Costa MCN, Hogan VK, Mota ELA, Oliveira NF. Diferenciais de raça/cor da pele em anos potenciais de vida perdidos por causas externas. Rev Saúde Pública 2009; 43:405-12.

28. Andrade AB, Brandão PRB. Geografia de Salvador. Salvador: EdUFBA; 2006.

29. Souza ML. Fobópole: o medo generalizado e a militarização da questão urbana. Rio de Janeiro: Bertrand Brasil; 2008.

30. Silva LMV, Paim JS, Costa MCN. Desigualdades na mortalidade, espaço social e estratos sociais. Rev Saúde Pública 1999; 33:187-97.

31. Bourdieu P. Razões práticas sobre a teoria da ação. 8a Ed. Campinas: Papirus; 2007.

32. Bourdieu P. A distinção, critica social do julgamento. São Paulo: Edusp/Zouk; 2006.

33. Souza KOJ. A pouca visibilidade da mulher brasileira no tráfico de drogas. Psicol Estud 2009; 14:649-57.

34. Lima MLC, Ximenes RAA, Feitosa CL, Souza ER, Albuquerque MFPM, Barros MDA, et al. Conglomerados de violência em Pernambuco, Brasil. Rev Panam Salud Pública 2005; 18:122-8. 
35. Szwarcwald CL, Castilho EA. Mortalidade por armas de fogo no estado do Rio de Janeiro, Brasil: uma análise espacial. Rev Panam Salud Pública 1998; 4:161-70.

36. Lozada EMK, Mathias AF, Andrade SM, Aidar T. Tendência da mortalidade por homicídios no Estado do Paraná, segundo regionais de saúde, 1979 a 2005. Rev Bras Epidemiol 2009; 12:258-69.

37. Santos SM, Barcellos C, Carvalho MS. Ecological analysis of the distribution and socio-spatial context of homicides in Porto Alegre, Brazil. Health Place 2006; 12:38-47.

38. Chamlin MB, Cochran JK. Economic inequality, legitimacy, and cross-national homicides rates. Homicide Stud 2006; 10:231-52.

39. Stults BJ. Determinants of Chicago neighborhood homicide trajectories: 1965-1995. Homicide Stud 2010; 14:244-67.

40. Morenoff JD, Sampson RJ, Raudenbush SW. Neighborhood inequality, collective efficacy, and the spatial dynamics of urban violence. Ann Arbor: Population Studies Center, University of Michigan; 2001. (Report, 00-451).

41. Gartner R. The victims of homicide: a temporal and cross-national comparison. Am Sociol Rev 1990; 55:92-106.

42. Messner SF, Raffalovich LE, Shrock P. Reassessing the cross-national between income inequality and homicide rates: implications of data quality control in the measurement of income distribution. J Quant Criminol 2002; 18:377-95.

43. Elgar FJ, Aitken N. Income inequality, trust and homicide in 33 countries. Eur J Public Health 2010; 21:241-6.

44. Thacher D. The rich get richer and the poor get robbed: inequality in U.S. criminal victimization, 1974-2000. J Quant Criminol 2004; 20:89-116.

45. Programa das Nações Unidas para o Desenvolvimento. Atlas do desenvolvimento humano no Brasil. Belo Horizonte: Fundação João Pinheiro/ Rio de Janeiro: Instituto Brasileiro de Geografia e Estatística; 2003.
46. Peres MFT, Cardia N, Mesquita Neto P, Santos PC, Adorno S. Homicídios, desenvolvimento socioeconômico e violência policial no município de São Paulo, Brasil. Rev Panam Salud Pública 2008; 23:268-76.

47. Zaluar A, Noronha JC, Albuquerque C. Violência ou fraqueza institucional? Cad Saúde Pública 1994; 10 Suppl 1:213-7.

48. Wacquant L. As duas faces do gueto. São Paulo: Boitempo Editorial; 2008.

49. Elias N. O processo civilizador: uma história dos costumes. v. 1. Rio de Janeiro: Jorge Zahar Editor; 1994.

50. Rouquayrol MZ, Almeida Filho N. Epidemiologia \& saúde. 6a Ed. Rio de Janeiro: Editora Medsi; 2003.

51. Schwartz S. The fallacy of the ecological fallacy: the potential misuse of a concept and the consequences. Am J Public Health 1994; 84:819-24.

52. Susser M. The logic in ecological: II. The logic of design. Am J Public Health 1994; 84:830-5.

53. Carvalho AT. Medindo desigualdades sociais na mortalidade: uma comparação de métodos no município de São Paulo [Teses de Doutorado]. Campinas: Universidade Estadual de Campinas; 2004.

54. Carvalho I, Pereira GC, organizadores. Como anda Salvador e sua Região Metropolitana. Salvador: EdUFBA; 2008.

55. Conselho Nacional de Secretários de Saúde. Violência: uma epidemia silenciosa. Seminários regionais. Brasília: Conselho Nacional de Secretários de Saúde; 2008. (CONASS Documenta, 16).

56. Conselho Nacional de Secretários de Saúde. Violência: uma epidemia silenciosa. Seminário nacional: propostas, estratégias e parcerias por áreas de atuação. Brasília: Conselho Nacional de Secretários de Saúde; 2008. (CONASS Documenta, 17).

57. Departamento de Análise de Situação de Saúde, Secretaria de Vigilância em Saúde, Ministério da Saúde. Viva: vigilância de violências e acidentes, 2006 e 2007. Brasília: Ministério da Saúde; 2009.

Submitted on $15 /$ Jun/2010

Final version resubmitted on 30/Nov/2010

Approved on 03/Jan/2011 